\title{
Two New and Closely Related Heterothallic Species, Pichia amylophila and Pichia mississippiensis: Characterization by Hybridization and Deoxyribonucleic Acid Reassociation
}

\author{
C. P. KURTZMAN, ${ }^{1}$ M. J. SMILEY, ' C. J. JOHNSON,' L. J. WICKERHAM, $\dagger$ AND G. B. FUSON ${ }^{2}$ \\ Northern Regional Research Center, Agricultural Research, Science and Education Administration, U.S. \\ Department of Agriculture, Peoria, Illinois 61604,' and Department of Food Science and Technology, \\ University of California, Davis, California $95616^{2}$
}

Two new species of the yeast genus Pichia were isolated from frass obtained from loblolly pines growing in Mississippi. The new taxa, designated Pichia amylophila and Pichia mississippiensis, are heterothallic, and Candida obtusa var. arabinosa proved to be a haploid member of the latter species. The species show interspecific mating, but ascospores from the crosses are infertile. The nuclear deoxyribonucleic acids from the species differ by $2 \mathrm{~mol} \%$ in guanine plus cytosine content and exhibit low (25\%) base sequence complementarity. Deoxyribonucleic acid relatedness was determined spectrophotometrically, and the methodology is given in detail.

During the isolation of yeasts from insect frass collected from pine trees in Mississippi, we recovered strains that were phenotypically similar to Pichia wickerhamii (van der Walt) Kregervan Rij and Pichia rhodanensis (Ramirez et Boidin) Phaff. These strains were heterothallic but failed to conjugate with mating types from either $P$. wickerhamii or $P$. rhodanensis. One of the newly isolated cultures differed from the others by its ability to assimilate starch, and genetic crosses between it and the other isolates gave only infertile and generally poorly formed ascospores. In an effort to clarify speciation, we examined the nuclear deoxyribonucleic acid (DNA) base sequence complementarity of the strains. As a result, the isolates proved to be of particular interest because they allowed an examination of species parameters through both genetic crosses and DNA reassociation studies.

\section{MATERIALS AND METHODS}

Culture isolation. Frass samples from shortleaf (Pinus echinata Mill.) and loblolly (Pinus taeda L.) pines were collected at the Piney Woods Country Life School of Piney Woods, Miss., in late October 1949, and sent by school personnel to the Northern Regional Research Center. Samples were directly streaked onto YM agar in petri plates and were enriched by incubation in liquid yeast nitrogen base supplemented with either glucose or rhamnose (21). Cultures were incubated at $25^{\circ} \mathrm{C}$. Resultant yeast colonies were isolated and further purified by streaking on YM agar.

Physiological and morphological characterization. The methods for the morphological examination and characterization by fermentation and assim-

† Present address: 5540 West Bar X Street, Tucson, AZ 85713. ilation tests were previously given (21). Single-ascospore isolates were obtained by micromanipulation. The criteria used for speciation within the genus $P i$ chia were those proposed by Kreger-van Rij (7).

DNA purification and determination of base composition. Extraction and purification of DNA were done by a combination of the procedures of Marmur (9) and Bernardi et al. (2) as described by Price et al. (15). The ratios of absorbance at $260 \mathrm{~nm}$ $\left(A_{260}\right) / A_{280}$ and $A_{230} / A_{260}$ were used to assess DNA purity. Purification was repeated if the preparation deviated more than 0.05 from the ratios $A_{260} / A_{280}=$ 1.86 and $A_{230} / A_{260}=0.5$ (11). The quality of the DNA was further assessed from analytical ultracentrifuge scans and from thermal-melt profiles. Hyperchromicity of the preparations ranged from 34.4 to $36.8 \%$.

The guanine plus cytosine $(\mathrm{G}+\mathrm{C})$ content of the nuclear DNA was calculated from buoyant density values in cesium chloride $(16,19)$ and was based on three or four separate determinations made with a Spinco model $\mathrm{E}$ analytical ultracentrifuge equipped with an electronic scanner. Micrococcus lysodeikticus Fleming DNA was used as a reference; this DNA had a buoyant density of $1.7311 \mathrm{~g} / \mathrm{ml}$ when compared to DNA from Escherichia coli K-12, whose density was taken to be $1.7100 \mathrm{~g} / \mathrm{ml}(16)$.

DNA reannealing reactions. The extent of DNA reassociation was determined spectrophotometrically, essentially by the method reported by Seidler and Mandel (18) and Seidler et al. (17), as described below. DNA was sheared by two passages through a French press at $10,000 \mathrm{lb} / \mathrm{in}^{2}$ and was recovered as intact double-stranded fragments. To increase the reaction rate, the reassociations were done in $5 \times \mathrm{SSC}(\mathrm{SSC}=$ standard saline citrate, $150 \mathrm{mM} \mathrm{NaCl}-15 \mathrm{mM}$ sodium citrate, $\mathrm{pH} 7.0$ ), but with the addition of $20 \%$ dimethylsulfoxide to depress the melting temperature (ca. $12^{\circ} \mathrm{C}$ ). Incubation times were approximately 2.5 to 3 $\mathrm{h}$ when the strains were highly related and 5 to $6 \mathrm{~h}$ when they were unrelated. The temperature for reas- 
sociations was $T_{m}-25^{\circ} \mathrm{C}$, and this was determined experimentally in $5 \times$ SSC-20\% dimethylsulfoxide. Incubation temperatures ranged from 54 to $58^{\circ} \mathrm{C}$ depending upon the $\mathrm{G}+\mathrm{C}$ content of the DNA. The concentration of DNA in the reaction mixture was adjusted to $75 \mu \mathrm{g} / \mathrm{ml}\left(A_{2(6)}=1.5\right)$; e.g., in a four-place cuvette holder, one cuvette contained only the incubation medium (blank), the second had $75 \mu \mathrm{g}$ of DNA from strain 1 per ml, the third had $75 \mu \mathrm{g}$ of DNA from strain 2 per $\mathrm{ml}$, and the fourth had a mixture of 37.5 $\mu \mathrm{g}$ of DNA from each of the two strains per ml (total of $75 \mu \mathrm{g} / \mathrm{ml}$ ).

Reassociation experiments were carried out with a model 250 recording spectrophotometer with a model 2527 thermoprogrammer (Gilford Instruments, Inc., Oberlin, Ohio). In the initial experiments, an early model thermoprogrammer cuvette block was used that consisted of four stainless steel cuvettes with removable quartz windows. To prevent the formation of large bubbles in the cuvettes during heating and cooling, the temperature was initially raised rapidly (ca. $12^{\circ} \mathrm{C} / \mathrm{min}$ ) to $75^{\circ} \mathrm{C}$, and the rate was then decreased to $3^{\circ} \mathrm{C} / \mathrm{min}$ until the temperature reached $90^{\circ} \mathrm{C}$. This was at least $5^{\circ} \mathrm{C}$ above the conclusion of the hyperchromic shift for the strains studied. The temperature was held at $90^{\circ} \mathrm{C}$ for $10 \mathrm{~min}$ to ensure complete denaturation of the DNA. Cooling to $T_{m}-25^{\circ} \mathrm{C}$ was at $3^{\circ} \mathrm{C} / \mathrm{min}$. Small bubbles, which usually formed at the periphery of the windows, were excluded from the light path by a sheet metal mask.

Later experiments used the newly designed thermoprogrammer block with four removable fused quartz cuvettes. Although bubbling seemed not to occur in these cuvettes, the same heating and cooling protocol was used as with the older cuvette block. Leakage around the Teflon stoppers of the quartz cuvettes was prevented by compressing a double layer of Teflon tape $(0.09 \mathrm{~mm}$ thick) into the filling port as the stopper was inserted.

Values for DNA relatedness obtained spectrophotometrically by using the quartz cuvettes were comparable to those from radioisotope studies as reported under Results. Data from the two types of cuvette assemblies were comparable in the mid to upper range of DNA relatedness, but in the lower range (ca. 0 to $30 \%$ ) the early model cuvettes gave readings 10 to $20 \%$ higher. In addition, variation between replicates was much greater. Consequently, only data obtained with the fused quartz cuvettes are presented.

The extent of DNA reassociation was calculated as percent relatedness by the equation of Seidler and Mandel (18): $\left\{1-\right.$ [obs. $\left.C_{0} t_{0.5}{ }^{\text {mix }}+\left(C_{0} t_{0.5}{ }^{100}-C_{0} t_{0.5}{ }^{0}\right)\right] /$ $\left.C_{0} t_{0.5}{ }^{100}\right\} \times 100$ where obs. $C_{0} t_{0.5}{ }^{\mathrm{mix}}$ is the observed $C_{0} t_{0.5}$ of a renatured mixture, $C_{0} t_{0.5}{ }^{100}$ is the $C_{0} t_{0.5}$ of the mixture expected if the two DNA molecules are identical in sequence, and $C_{0} t_{0.5}{ }^{0}$ is the $C_{0} t_{0.5}$ of the mixture expected for no sequence similarity (complete additivity of the independently measured $C_{0} t_{0.5}$ values).

\section{RESULTS}

Spectrophotometric determination of DNA relatedness. Seidler and Mandel (18) reported that their method for spectrophotometric measurement of reassociation of bacterial
DNA gave results comparable to those obtained with radicisotope techniques. The Seidler-Mandel method appears not to have been previously used to measure reassociation of yeast DNA. In view of this, we selected for comparison yeast strains that were studied earlier with radioisotope-labeled DNA. Price and collaborators (15) employed ${ }^{32} \mathrm{P}$-labeled DNA and hydroxylapatite fractionation in an extensive study of speciation in four genera. For comparison, we chose four pairs from that study and used the same strains. Despite procedural differences, our results with the spectrophotometric method were quite similar to those presented by Price et al. (Table 1).

The renaturation kinetics of DNA from Debaryomyces hansenii determined spectrophotometrically are depicted in Fig. 1A along with a theoretical second-order plot calculated from the equation of Britten and Kohne (3). It is apparent that reassociation departs from theoretical second-order kinetics, and this has been noted in other studies $(15,18)$. By using a Wetmur-Davidson (20) plot, we estimated the DNA preparation to be composed of $94 \%$ unique and $6 \%$ repetitive, rapidly renaturing sequences (Fig. 1B).

DNA from other strains used in this study contained no more than 5 to $8 \%$ repetitive sequences, and this was comparable to preparations obtained by Price et al. (15) with hydroxylapatite fractionation of DNA renatured to a $C_{0} t$ value of 0.1 to 0.2 . In our spectrophotometric system, approximately $12 \mathrm{~min}$ elapsed between the conclusion of the DNA melt at $90^{\circ} \mathrm{C}$ and the start of measurement of reassociation at $T_{m}$ $25^{\circ} \mathrm{C}$. It appears that a major portion of the repetitive sequences renature during the cool down and are excluded from the measurement of relatedness.

Description of new taxa. Latin diagnosis of Pichia amylophila sp. nov. Species heterothallica. Asci dehiscentes, 2-4 ascosporos piliformes habentes (1.5-2.2 $\times$ 3.0-3.5 $\mu \mathrm{m})$. Asci spheroidales-ellipsoidales $(4.0-5.0 \times 4.5-7.0 \mu \mathrm{m})$, alii liberi, alii adnexi, sessiles seu brevibus sterigmatibus retenti.

In agare maltoso cellulae singulae, aut aliquando dispositae in racemis, plerumque spheroidales-ellipsoidales seu elongatae $(2.0-5.5 \times 3$ $14 \mu \mathrm{m})$. Pseudohyphae copiosae; hyphae verae (1.8-2.5 $\mu \mathrm{m}$ diametro) rarae. In agare morphologico incrementum eburneum, nubilum, umidum; margo serrata, centrum paulum sublatum.

Glucosum acriter fermentatur; galactosum, maltosum, sucrosum, lactosum, raffinosum, et trehalosum non fermentantur.

Assimilantur glucosum, sucrosum, maltosum, cellobiosum, trehalosum, melezitosum, amylum solubile, D-xylosum, L-arabinosum, ethanolum, 
TABLE 1. Comparison of the spectrophotometric method with a radioisotope technique for measuring DNA reassociation between species of Debaryomyces and Pichia

\begin{tabular}{|c|c|c|}
\hline Test pair and strain no. & $\begin{array}{c}\text { \% DNA relatedness assessed spectro- } \\
\text { photometrically }{ }^{a}\end{array}$ & $\begin{array}{l}\text { Do DNA relatedness assessed us- } \\
\text { ing }{ }^{3: 2} \text { P-labeled DNA }{ }^{b}\end{array}$ \\
\hline $\begin{array}{l}\text { D. hansenii and D. tyrocola } \\
\text { NRRL Y-7426, NRRL Y-1458 } \\
\text { CBS 767, CBS } 766 \\
\text { UCD } 74-86 \text {, UCD } 72-47\end{array}$ & $75 \pm 3.0$ & $77 \pm 1.0$ \\
\hline $\begin{array}{l}\text { D. vanriji and } D . \text { yarrowii } \\
\text { NRRL Y-7430, NRRL Y-7535 } \\
\text { CBS } 3024 \text {, CBS } 6246 \\
\text { UCD } 61-24 \text {, UCD } 72-48\end{array}$ & $71 \pm 2.3$ & $68 \pm 1.2$ \\
\hline $\begin{array}{l}\text { D. hansenii and D. subglobosus } \\
\text { NRRL Y-7426, NRRL Y-6666 } \\
\text { CBS 767, CBS } 792 \\
\text { UCD 74-86, UCD } 75-17\end{array}$ & $44 \pm 1.4$ & $40 \pm 2.6$ \\
\hline $\begin{array}{l}\text { D. hansenii and } P \text {. vini var. vini } \\
\text { NRRL Y-7426, NRRL Y-1459 } \\
\text { CBS 767, CBS } 810 \\
\text { UCD } 74-86 \text {, UCD } 66-20\end{array}$ & $2 \pm 1.9$ & $2.7 \pm 0.7$ \\
\hline
\end{tabular}

${ }^{a}$ Standard deviation calculated from three determinations.

${ }^{b}$ Data from Price et al. (15).

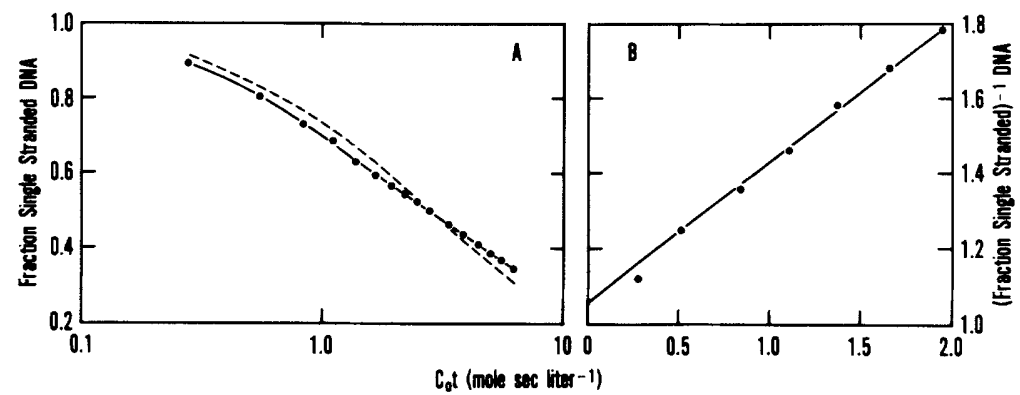

FIG. 1. Reassociation kinetics of DNA from Debaryomyces hansenii NRRL Y-7426 determined spectrophotometrically. (A) Comparison of experimental data (solid line) with theoretical second-order plot (dashed line) calculated by the method of Britten and Kohne (3); (B) early data points presented in second-order rate plot after Wetmur and Davidson (20).

glycerolum, D-mannitolum, D-glucitolum, $\alpha$ methyl-D-glucosidum, potassii D-gluconas, acidum DL-lacticum, acidum succinicum, et acidum citricum. Non assimilantur galactosum, L-sorbosum, lactosum, melibiosum, raffinosum, inulinum, D-arabinosum, D-ribosum, L-rhamnosum, D-glucosaminum.HCL, $i$-erythritolum, ribitolum, galactitolum, salicinum, calcii 2-ketogluconas, potassii 5-ketogluconas, potassii-sodii saccharas, ethylacetoacetas, $i$-inositol, et potassii nitras. In medio vitaminibus carente augmentum non fit. Augmentum copiosum in temperatura $37^{\circ} \mathrm{C}$. Amylum non fit; esteres non fiunt; gelatinum non liquescit.

Typus: NRRL YB-1287 (CBS 7020) designat stirpem typicam. Isolatur a fimo scarabaeorum collecto a Pinus taeda L. apud Piney Woods,
Miss., United States. Typi conjungentes complementarii: NRRL YB-1287-82-2 (CBS 7021) et NRRL YB-1287-82-3 (CBS 7022). Culturae servantur in Collectione Culturarum, Officina Investigationum Tractus Borealis, Peoria, Ill., United States.

Description of $\boldsymbol{P}$. amylophila. Growth on malt extract agar: After 3 days at $25^{\circ} \mathrm{C}$, the cells are single or rarely clustered, spheroidal, ellipsoidal, or elongate ( 2.0 to 5.5 by 3 to $14 \mu \mathrm{m}$ ). Pseudohyphae are abundant and well branched. True hyphae (diameter: 1.8 to $2.5 \mu \mathrm{m}$ ) are rarely seen and show no evidence of a dolipore septum when viewed under the light microscope with an oil immersion objective (Fig. 2).

Growth on morphology agar: After 7 days at $25^{\circ} \mathrm{C}$, growth is cream colored, dull, and moist 

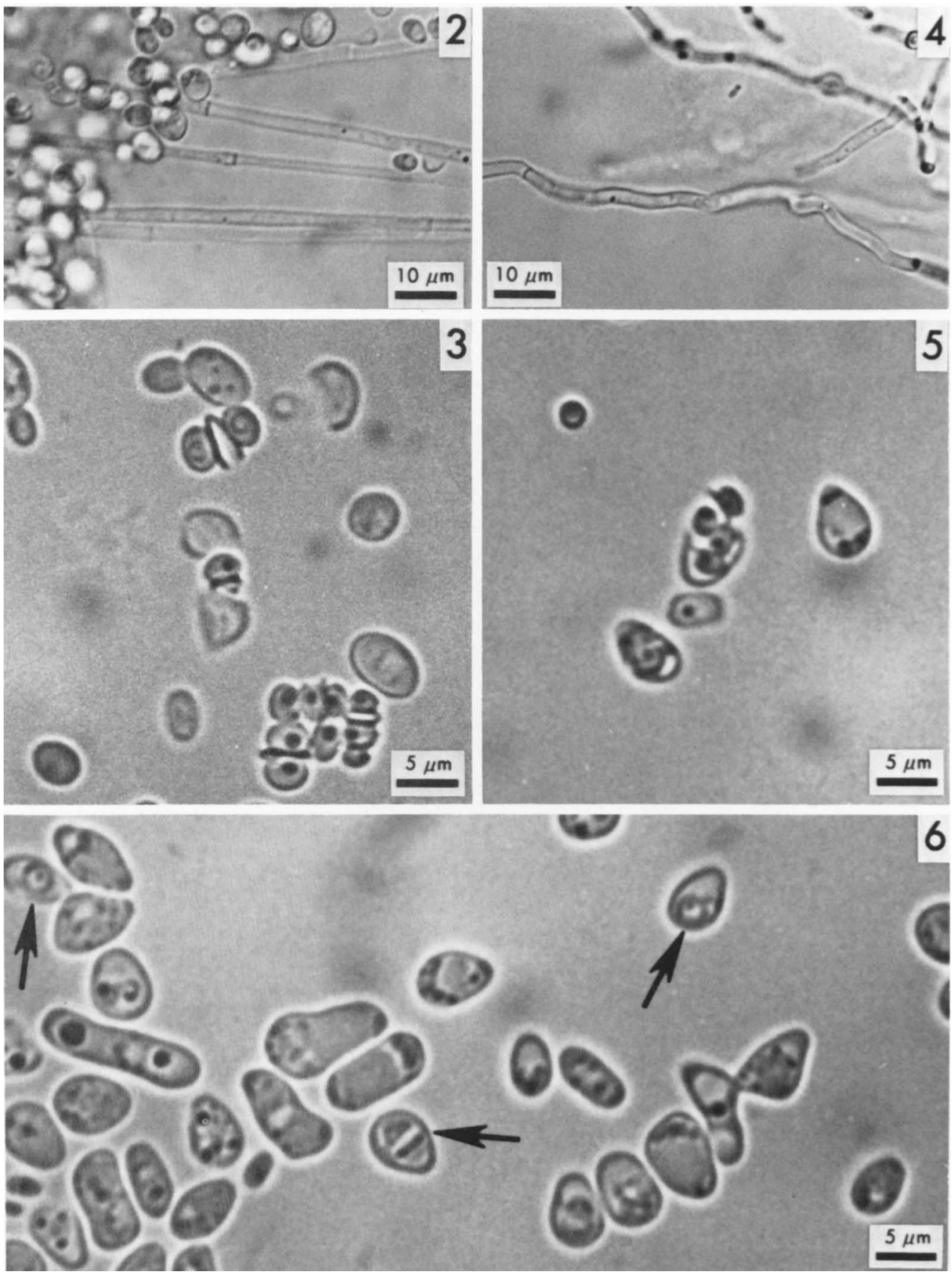

Fig. 2. P. amylophila NRRL YB-1287. True hyphae with septa.

FIG. 3. P. amylophila NRRL YB-1287. Dehisced ascospores and ascus fragments. Diploid ascospores are noticeably larger than the haploid ascospores which are also present.

FIG. 4. P. mississippiensis NRRL YB-1294. True hypha with septum.

FIG. 5. P. mississippiensis NRRL YB-1294. Dehiscense of ascospores from a four-spored ascus.

FIG. 6. P. amylophila NRRL YB-1287-82-3 $\times$ P. mississippiensis NRRL YB-1294-6. Conjugated cells (right, center) and asci with aborted spores (arrows). 
with a serrate margin and a slightly raised center.

Sexual reproduction: Diploid cultures formed ascospores quite abundantly on $5 \%$ malt extract agar at $25^{\circ} \mathrm{C}$ after 7 to 10 days. Sporulation was nearly as good on YM agar. Two hat-shaped ascospores ( 1.5 to 2.2 by 3.0 to $3.5 \mu \mathrm{m}$ ) were formed in each dehiscent ascus (Fig. 3). Asci are spheroidal to ellipsoidal (4.0 to 5.0 by 4.5 to 7.0 $\mu \mathrm{m})$ and generally are free, but they may be attached and sessile or attached by short sterigmata to pseudohyphae.

Isolation of 83 single ascospores from NRRL YB-1287 (viability, 76/83) gave 70 that produced sporogenous colonies and 6 that formed asporogenous colonies. There was no sporulation in mixtures of asporogenous colonies. Two of the sporogenous colonies (strains 44 and 82 ) infrequently produced three- to four-spored asci. Single-spore isolates from strain 82 (viability $25 / 37$, sporogenous 14, asporogenous 11) yielded asporogenous colonies that sporulated when mixed, thus showing $P$. amylophila to be heterothallic despite the tendency of the parent strain to produce predominantly diploid spores. NRRL YB-1287-82-2 (a) and NRRL YB-1287-82-3 $(\alpha)$ were selected as representative complementary mating types. Asci from this pair predominantly formed three to four spores.

Fermentation: Glucose was strongly fermented. A bubble formed in maltose and sucrose tubes after 24 days. There was no fermentation of galactose, lactose, raffinose, or trehalose.

Assimilation of carbon compounds: Glucose, sucrose, maltose, cellobiose, trehalose, melezitose, soluble starch, D-xylose, L-arabinose, ethanol, glycerol, D-mannitol, D-glucitol, $\alpha$ methyl-D-glucoside, potassium-D-gluconate, DL- lactic acid, succinic acid, and citric acid were utilized as sole carbon sources.

Carbon compounds not assimilated: Galactose, L-sorbose, lactose, melibiose, raffinose, inulin, D-arabinose, D-ribose, L-rhamnose, D-glucosamine-hydrochloride, $i$-erythritol, ribitol, galactitol, salicin, calcium-2-ketogluconate, potassium-5-ketogluconate, potassium sodium saccharate, ethylacetoacetate, and $i$-inositol were not utilized as sole carbon sources.

Assimilation of potassium nitrate: negative.

Growth in vitamin-free medium: negative.

Growth in $10 \%$ sodium chloride plus $5 \%$ glucose in yeast nitrogen base: negative.

Growth at $37^{\circ} \mathrm{C}$ : positive.

Starch formation: negative.

Production of esters: negative.

Liquefaction of gelatin: negative.

$\mathrm{G}+\mathrm{C}$ content of the nuclear DNA: $45.4 \mathrm{~mol} \%$.

Type: The type strain, NRRL YB-1287, the only known strain of this species, was isolated from frass collected from loblolly pine, Pinus taeda L., in late October 1949, from Piney Woods, Miss. (Table 2).

Latin diagnosis of Pichia mississippiensis sp. nov. Species heterothallica. Asci dehiscentes, 24 ascosporos piliformes $(1.5-2.0 \times 2.5-3.5 \mu \mathrm{m})$ habentes. Asci spheroidales-ellipsoidales (3.0$5.0 \times 4.5-6.5 \mu \mathrm{m})$, liberi seu adnexi ad pseudohyphas; aliquando a cellula pseudohyphali seu hyphali fit ascus.

In agare maltoso cellulae singulae, aliquando binae aut in racemis, plerumque ellipsoidaleselongatae, rare spheroidales, multo discrepantes magnitudine $(1.1-5.0 \times 2.0-12.0 \mu \mathrm{m})$. Pseudohyphae copiosae, hyphae verae $(1.7-3.0 \mu \mathrm{m}$ diametro) rarae. In agare morphologico incrementum fuscum pallidum, nitens, butyrosum; cen-

TABLE 2. Sources and ploidy of strains of P. amylophila and P. mississippiensis

\begin{tabular}{lll}
\hline Species and NRRL no. & \multicolumn{1}{c}{ Habitat } & Ploidy/mating type $^{a}$ \\
\hline $\begin{array}{l}\text { P. amylophila } \\
\text { YB-1287 }\end{array}$ & Frass, loblolly pine & \\
$\begin{array}{l}P \text {. mississippiensis } \\
\text { YB-1269 }\end{array}$ & Frass, shortleaf pine & Diploid \\
YB-1270 & Frass, shortleaf pine & Haploid/a \\
YB-1276 & Frass, loblolly pine & Haploid/a \\
YB-1285 & Frass, shortleaf pine & Haploid/a \\
YB-1286 & Frass, shortleaf pine & Haploid/a \\
YB-1290 & Frass, shortleaf pine & Haploid/a \\
YB-1291 & Frass, loblolly pine & Haploid/a \\
YB-1292 & Frass, loblolly pine & Unknown \\
YB-1294 & Frass, loblolly pine & Haploid/ $\alpha$ \\
YB-1317 & Laboratory contaminant (probably & Haploid/a \\
& from above samples) & \\
\hline
\end{tabular}

${ }^{a}$ The $\mathbf{a}$ and $\alpha$ designations are used for convenience and have not been correlated with the $\mathbf{a}$ and $\alpha$ mating types of Saccharomyces cerevisiae. 
trum coloniae sublatum, margo non fractum. Cultura olet subacidum sed suave.

Glucosum vehementer fermentatur. Galactosum, maltosum, sucrosum, lactosum, raffinosum, trehalosum non fermentantur.

Assimilantur glucosum, sucrosum, maltosum, cellobiosum, trehalosum, melezitosum, D-xylosum, L-arabinosum, D-arabinosum (imbecillum, negativum), L-rhamnosum (positivum, negativum), ethanolum, glycerolum, D-mannitolum, D-glucitolum, $\alpha$-methyl-D-glucosidum, salicum, (positivum, imbecillum, negativum), potassi D-gluconas, DL-acidum lacticum, acidum succinicum, acidum citricum (positivum, negativum). Non assimilantur galactosum, L-sorbosum, lactosum, melibiosum, raffinosum, inulinum, amylum solubile, D-ribosum, D-glucosaminum $\cdot \mathrm{HCl}, i$-erythritolum, ribitolum, galactitolum, calcii 2-ketogluconas, potassii 5-ketogluconas, potassii-sodii saccharas, ethylacetoacetas, $i$-inositolum, potassii nitras. Nullum augmentum si medium caret vitaminis. Augmentum copiosum in temperatura $37^{\circ} \mathrm{C}$. Amylum non fit; esteres non fiunt; gelatinum non liquescit.

Typus NRRL YB-1294 (CBS 7023) designat stirpem typicam. Isolatur a fimo scarabaeorum a Pinus taeda L. apud Piney Woods, Miss., United States. Typi conjungentes complementarii: NRRL YB-1294-6 (CBS 7024) et NRRL 1294-7 (CBS 7025). Culturae servantur in Collectione Culturarum, Officina Investigationum Tractus Borealis, Peoria, Ill., United States.

Description of $P$. mississippiensis. Growth on malt extract agar: After 3 days at $25^{\circ} \mathrm{C}$, the cells are single or infrequently in pairs or clusters. Cells are ellipsoidal to elongate, or occasionally spheroidal, and quite variable in size ( 1.1 to 5.0 by 2.0 to $12.0 \mu \mathrm{m}$ ). Pseudohyphae are abundant and well developed. True hyphae (diameter: 1.7 to $3.0 \mu \mathrm{m}$ ) are uncommon and show no evidence of a dolipore septum when viewed under the light microscope with an oil immersion objective (Fig. 4).

Growth on morphology agar: After 7 days at $25^{\circ} \mathrm{C}$, growth is light tan, glistening, and butyrous; the colony center is raised; and the margin entire. The culture has a faint, pleasant acidic odor.

Sexual reproduction: Cultures formed abundant ascospores on YM agar and on 5\% malt extract agar at $25^{\circ} \mathrm{C}$ after 5 to 8 days. Two to four hat-shaped ascospores ( 1.5 to 2.0 by 2.5 to $3.5 \mu \mathrm{m})$ were formed in each dehiscent ascus (Fig. 5). Asci are spheroidal to ellipsoidal (3.0 to 5.0 by 4.5 to $6.5 \mu \mathrm{m}$ ) and are free or attached to pseudohyphae. Infrequently, a pseudohyphal or hyphal cell became an ascus.

Single ascospore isolates (viability, 26/31) pro- duced asporogenous colonies. The species was demonstrated to be heterothallic through pairing of appropriate single-spore isolates. NRRL YB-1294-6 (a) and NRRL YB-1294-7 $(\alpha)$ were selected as representative complementary mating types.

Fermentation: Glucose was strongly fermented, and occasionally a bubble formed in maltose and sucrose tubes. There was no fermentation of galactose, lactose, raffinose, or trehalose.

Assimilation of carbon compounds: Glucose, sucrose, maltose, cellobiose, trehalose, melezitose, D-xylose, L-arabinose, D-arabinose (weak or negative), L-rhamnose (positive or negative), ethanol, glycerol, D-mannitol, D-glucitol, $\alpha$ methyl-D-glucoside, salicin (positive, weak, or negative), potassium-D-gluconate, DL-lactic acid, succinic acid, and citric acid (positive or negative) were utilized as sole carbon sources.

Carbon compounds not assimilated: Galactose, L-sorbose, lactose, melibiose, raffinose, inulin, soluble starch, D-ribose, D-glucosamine. hydrochloride, $i$-erythritol, ribitol, galactitol, calcium-2-ketogluconate, potassium-5-ketogluconate, potassium sodium saccharate, ethylacetoacetate, and $i$-inositol were not utilized as sole carbon sources.

Assimilation of potassium nitrate: negative.

Growth in vitamin-free medium: negative.

Growth in $10 \%$ sodium chloride plus $5 \%$ glucose in yeast nitrogen base: negative.

Growth at $37^{\circ} \mathrm{C}$ : positive.

Starch formation: negative.

Production of esters: negative.

Liquefaction of gelatin: negative.

$\mathrm{G}+\mathrm{C}$ content of the nuclear DNA: 47.2 to 48.0 mol\% (range of three strains, Table 3 ).

Type: NRRL YB-1294, the type strain, was isolated from frass collected from a loblolly pine, Pinus taeda L., in late October 1949, from Piney Woods, Miss. Other strains of this species are listed in Table 2.

Candida obtusa var. arabinosa Montrocher (14) was isolated from Cliptopilus prunulus (Scop. ex Fr.) Kummer in France and appeared identical to haploid forms of $P$. mississippiensis. Abundant conjugation and sporulation resulted when the type strain (NRRL Y-11,748 = CBS 5837 ) of this asexual yeast was mixed with YB1294-7. Single-spore isolates from this pairing exhibited good viability ( $30 / 34$ viable), and appropriate sibling pairs formed mature ascospores.

By means of standard fermentation and assimilation tests, $P$. amylophila is separated from $P$. mississippiensis only by its ability to assimilate soluble starch. Nine single-spore isolates from 
NRRL YB-1287 or from crosses of its progeny were tested for starch utilization and all were found positive, so the character appeared reliable for separation of these two species.

Interspecific mating tests. Initially, the two new species were considered to represent the same taxon, but their difference in starch assimilation prompted us to undertake genetic crosses between them. Data in Table 4 show that the frequency of interspecific conjugation is comparable to that for intraspecific pairings; however,

TABLE 3. Nuclear DNA base composition of $P$. amylophila, $P$. mississippiensis, and similar species

\begin{tabular}{|c|c|}
\hline Species and NRRL no. & $\mathrm{G}+\mathrm{C} \pm \mathrm{SD}^{a}(\mathrm{~mol} \%)$ \\
\hline $\begin{array}{l}\text { P. amylophila } \\
\text { YB- } 1287^{b}\end{array}$ & $45.4 \pm 0.00$ \\
\hline $\begin{array}{l}\text { P. mississippiensis } \\
\text { YB-1269 } \\
\text { YB-1294 } \\
\text { YB-1317 }\end{array}$ & $\begin{array}{l}47.7 \pm 0.08 \\
47.2 \pm 0.10 \\
48.0 \pm 0.15\end{array}$ \\
\hline $\begin{array}{l}\text { P. rhodanensis } \\
\text { Y-7854 } \\
\text { YB-651 sm-14 }\end{array}$ & $\begin{array}{l}51.9 \pm 0.12 \\
51.8 \pm 0.09\end{array}$ \\
\hline $\begin{array}{l}\text { P. wickerhamii } \\
\mathrm{Y}-2435^{b}\end{array}$ & $46.5 \pm 0.14$ \\
\hline $\begin{array}{l}\text { C. obtusa var. arabinosa } \\
\mathrm{Y}-11,748^{b}\end{array}$ & $47.4 \pm 0.11$ \\
\hline
\end{tabular}

${ }^{a}$ Standard deviation (SD) calculated from three to four determinations.

${ }^{b}$ Type strain. most of the ascospores resulting from interspecific crosses were poorly formed (Fig. 6). The results were similar when the other haploid strains of $P$. mississippiensis, including $C$. $o b$ tusa var. arabinosa, were paired with $P$. amylophila. Because of the rarity of apparently mature spores from interspecific crosses, singlespore isolations proved difficult, but the few spores isolated were not viable (Table 4). With the exception of NRRL YB-1291, which failed to sporulate or to show mating competence, all haploid strains of $P$. mississippiensis gave at least $50 \%$ ascospore viability when paired with the appropriate mating type from NRRL YB1294.

In further comparisons, mating types of $P$. amylophila and P. mississippiensis were paired with mating types from the phenotypically similar heterothallic species $P$. wickerhamii (NRRL Y-2435-9, NRRL Y-2435-10), $P$. rhodanensis (NRRL YB-651 sm-14, NRRL Y-7854 Re-1), and $P$. veronae Kodama (NRRL Y-7818-1, NRRL Y-7818-10). Mating responses were not detected in these mixtures or in interspecific mixtures of mating types from the latter three species.

DNA reassociation studies. Consistent with results from genetic crosses, DNA reassociation experiments showed high (96 to 99\%) base sequence complementarity between strains of $P$. mississippiensis but low (20 to $27 \%$ ) complementarity between $P$. mississippiensis and $P$. amylophila (Table 5). Nonetheless, the limited extent of reassociation shown between these two species was still noticeably higher than that

TABLE 4. Reaction between mating types from P. amylophila NRRL YB-1287 and P. mississippiensis NRRL $Y B-1294$

\begin{tabular}{|c|c|c|}
\hline Mating types ${ }^{a}$ & Reaction & $\begin{array}{c}\text { Ascospore viability } \\
(\%)\end{array}$ \\
\hline YB-1287-82-2 + YB-1287-82-3 & $\begin{array}{l}35 \% \text { conjugation; } 40 \% \text { of conjugants } \\
\text { formed ascospores }\end{array}$ & $100(46 / 46)$ \\
\hline YB-1294-6 + YB-1294-7 & $\begin{array}{l}15 \% \text { conjugation; } 65 \% \text { of conjugants } \\
\text { formed ascospores }\end{array}$ & $98(44 / 45)$ \\
\hline YB-1287-82-2 + YB-1294-6 & No conjugation; no ascospores & \\
\hline YB-1287-82-2 + YB-1294-7 & $\begin{array}{l}10 \% \text { conjugation; } 5 \% \text { of conjugants } \\
\text { formed ascospores. Dehisced, appar- } \\
\text { ently mature ascospores were no } \\
\text { more frequent than } 1 \text { per } 2 \times 10^{4} \\
\text { cells }^{c}\end{array}$ & Not determined \\
\hline YB-1287-82-3 + YB-1294-6 & $\begin{array}{l}20 \% \text { conjunction; } 5 \% \text { of conjugants } \\
\text { formed ascospores. Dehisced, appar- } \\
\text { ently mature ascospores were no } \\
\text { more frequent than } 1 \text { per } 2 \times 10^{4} \\
\text { cells }^{c}\end{array}$ & $0(0 / 4)$ \\
\hline YB-1287-82-3 + YB-1294-7 & No conjugation; no ascospores & \\
\hline
\end{tabular}

\footnotetext{
${ }^{a}$ When grown alone, mating types showed neither conjugations nor ascospores.

${ }^{b}$ Determined by single ascospore isolation of dehisced ascospores.

'Dehisced, apparently mature ascospores from interspecific crosses were approximately 1.5 times larger than ascospores from intraspecific crosses, and only two were formed per ascus.
} 
TABLE 5. DNA reassociation reactions between $P$. amylophila, $P$. mississippiensis, and other yeast species

\begin{tabular}{|c|c|c|c|}
\hline \multirow[b]{2}{*}{ Species and NRRL no. } & \multicolumn{3}{|c|}{$\%$ DNA reassociation $\pm \mathrm{SD}^{\alpha}$ between test pairs } \\
\hline & $\begin{array}{l}\text { P. amylophila } \\
\text { YB-1287 }\end{array}$ & $\begin{array}{l}\text { P. mississippiensis } \\
\text { YB-1294 }^{b}\end{array}$ & $\begin{array}{c}\text { P. rhodanensis } \\
\mathrm{Y}-7854^{b}\end{array}$ \\
\hline P. amylophila YB- $1287^{b}$ & & & $6 \pm 3.4$ \\
\hline P. mississippiensis YB- 1269 & $25 \pm 1.2$ & $99 \pm 2.0$ & \\
\hline P. mississippiensis YB-1294 & $27 \pm 2.3$ & & $4 \pm 2.1$ \\
\hline P. mississippiensis YB-1317 & $20 \pm 0.9$ & $96 \pm 1.2$ & \\
\hline Candida obtusa var. arabinosa $\mathrm{Y}-11,748^{b}$ & $23 \pm 3.3$ & $98 \pm 1.5$ & \\
\hline Pichia wickerhamii Y-2435 & $8 \pm 3.6$ & $4 \pm 1.4$ & $0 \pm 1.3$ \\
\hline Hansenula petersonii YB-3808 ${ }^{b}$ & $9 \pm 2.0$ & $7 \pm 1.9$ & \\
\hline
\end{tabular}

"Standard deviation calculated from three determinations.

${ }^{h}$ Type strain.

obtained when they were compared with such unrelated species as $P$. rhodanensis, $P$. wickerhamii, or Hansenula petersonii.

Results from the DNA studies parallel those from genetic crosses and confirm C. obtusa var. arabinosa to be the imperfect form of $P$. mississippiensis. It is also evident from these data that $P$. wickerhamii and $P$. rhodanensis represent distinct species.

\section{DISCUSSION}

Determination of relatedness between microorganisms by comparison of their nuclear DNA can be accomplished by several methods. One of the commonest techniques involves incubating unsheared single-stranded DNA immobilized on nitrocellulose filters in the presence of sheared single-stranded DNA labeled with radioisotopes. At the conclusion of the reaction, the amount of reassociation is measured by the amount of radioactivity retained by the filter $(5,6)$. Price and co-workers (15) used radioactive DNA in their study of relatedness among yeasts, but the protocol differed in that the double-stranded DNA was bound to hydroxylapatite after completion of the renaturation reaction. Measurement of radioactivity in bound and unbound fractions allowed assessment of relatedness.

The spectrophotometric method for measuring reassociation is particularly attractive when difficulties are encountered with in vivo radioisotope labeling of DNA or where numerous pairwise comparisons are to be made and the time required for labeling becomes excessive. The spectrophotometric method has been used in studies of bacteria (e.g., 4, 17, 18), and results were similar to those obtained with radioisotopes. Martini and Phaff (10) used the spectrophotometric method of De Ley et al. (4) with some success to compare relatedness among yeasts, but the procedure of Seidler and Mandel (18), which monitors the reaction over a much longer period, has not been applied to yeast systematics. Our results showed good correlation with data obtained by radioisotope studies (15) and suggest that the spectrophotometric technique of Seidler and Mandel may be reliably applied to yeasts and probably other eucaryotes.

In recent years, yeast taxonomists have turned increasingly to the use of DNA base sequence comparisons for clarification of species relationships that defy solution by traditional means (1, $11-13,15)$. Relatedness values of 20 to $25 \%$ or less were taken to mean that the strains in question represented different species, whereas values of 80 to $100 \%$, as suggested by Price et al. (15), indicated that strains belong to the same species. Values in the 20 to $80 \%$ range seldom have been found, and too little data are presently available for an understanding of their significance.

Results from mating tests between $P$. amylophila and P. mississippiensis suggested considerable genetic homology between these two species despite the lack of viable ascospores. Consequently, it was quite surprising to find that the species exhibited only about $25 \%$ DNA relatedness. In comparisons between Pichia scutulata Phaff et al., var. scutulata and P. scutulata var. exigua, an even greater contrast was shown (Kurtzman et al., unpublished data). The varieties exhibited only about $25 \%$ base sequence complementarity, yet fertile ascospores (ca. 5\%) were occasionally formed from intervarietal crosses. Furthermore, sibmatings between these ascosporic isolates gave viable ascospores.

Winge and Laustsen (23) and Wickerman and Burton (22) have proposed that interfertility among yeasts be considered indicative of conspecificity. However, failure to mate cannot exclude conspecificity because progeny derived from the same diploid parent have been noted to lack mating competence (8). Consequently, the decision to consider $P$. amylophila and $P$. mississippiensis as separate species was made on the basis of both their limited DNA related- 
ness and their inability to form viable ascospores.

The use of fertility as the sole criterion for speciation must be carefully considered, for this would require that the varieties of $P$. scutulata be assigned to the same species even though the extent of their DNA relatedness is the same as that of the new Pichia species described here. Conversely, defining species strictly on the basis of a certain percentage of DNA relatedness may conflict with the biological reality of genetic exchange. Almost certainly, considerable latitude will be found in the definition of species even at the genetic and molecular levels. For the present, our data suggest that DNA base sequence complementarity as low as $25 \%$ may not preclude conspecificity since sufficient genetic compatibility can exist between some strains to allow sexual reproduction.

\section{ACKNOWLEDGMENTS}

We are greatly indebted to $H$. J. Phaff, Department of Food Science and Technology, University of California, Davis, for allowing one of us (C.P.K.) use of laboratory facilities where the preliminary isolation and characterization of DNA used in this study was accomplished. We thank C. W. Price for helpful suggestions on experimental protocol and for critical review of the manuscript. H. C. Nielsen and K. R. Sexson generously gave suggestions on the operation of the Spinco model $\mathbf{E}$ analytical ultracentrifuge used for determination of $\mathrm{G}+\mathrm{C}$ values. $\mathrm{H}$. M. Howe kindly provided the Latin diagnoses of the new species.

\section{REPRINT REQUESTS}

Address reprint requests to: Dr. C. P. Kurtzman, Northern Regional Research Center, 1815 N. University St., Peoria, IL 61604 .

\section{LITERATURE CITED}

1. Bak, A. L., and A. Stenderup. 1969. Deoxyribonucleic acid homology in yeasts. Genetic relatedness within the genus Candida. J. Gen. Microbiol. 59:21-30.

2. Bernardi, G., M. Foures, G. Piperno, and P. P. Slonimski. 1970. Mitochondrial DNAs from respiratory-sufficient and cytoplasmic respiratory-deficient mutants of yeast. J. Mol. Biol. 48:23-43.

3. Britten, R. J., and D. E. Kohne. 1968. Repeated sequences in DNA. Science 161:529-540.

4. De Ley, J., H. Cattoir, and A. Reynaerts. 1970. The quantitative measurement of DNA hybridization from renaturation rates. Eur. J. Biochem. 12:133-142.

5. Denhardt, D. T. 1966. A membrane filter technique for the detection of complementary DNA. Biochem. Biophys. Res. Commun. 23:641-646.

6. Gillespie, D., and S. Spiegelman. 1965. A quantitative assay for DNA-RNA hybrids with DNA immobilized on a membrane. J. Mol. Biol. 12:829-842.

7. Kreger-van Rij, N. J. W. 1970. Pichia Hansen, p. 455554. In J. Lodder (ed.), The yeasts-a taxonomic study. North-Holland Publishing Co., Amsterdam.

8. Kurtzman, C. P., and M. J. Smiley. 1976. Heterothallism in Pichia kudriavzevii and Pichia terricola. Antonie van Leeuwenhoek J. Microbiol. Serol. 42:355-363.

9. Marmur, J. 1961. A procedure for the isolation of DNA from microorganisms. J. Mol. Biol. 3:208-218.

10. Martini, A., and H. J. Phaff. 1973. The optical determination of DNA-DNA homologies in yeasts. Ann. Microbiol. 23:59-68.

11. Mendonça-Hagler, L. C., and H. J. Phaff. 1975. Deoxyribonucleic acid base composition and deoxyribonucleic acid/deoxyribonucleic acid hybrid formation in psychrophobic and related yeasts. Int. J. Syst. Bacteriol. 25:222-229.

12. Meyer, S. A., K. Anderson, R. E. Brown, M. T. Smith, D. Yarrow, G. Mitchell, and D. G. Ahearn. 1975. Physiological and DNA characterization of Candida maltosa, a hydrocarbon utilizing yeast. Arch. Microbiol. 104:225-231.

13. Meyer, S. A., R. E. Brown, and M. T. Smith. 1977. Species status of Hanseniaspora guilliermondii Pijper. Int. J. Syst. Bacteriol. 27:162-164.

14. Montrocher, R. 1967. Quelques nouvelles espèces et variétés du genre Candida (levures asporogènes). Rev. Mycol. 32:689-92.

15. Price, C. W., G. B. Fuson, and H. J. Phaff. 1978. Genome comparison in yeast systematics: delimitation of species within the genera Schuanniomyces, Saccha. romyces, Debaryomyces, and Pichia. Microbiol. Rev. 42:161-193.

16. Schildkraut, C. L., J. Marmur, and P. Doty. 1962. Determination of the base composition of deoxyribonucleic acid from its buoyant density in $\mathrm{CsCl}$. J. Mol. Biol. 4:430-433.

17. Seidler, R. J., M. D. Knittel, and C. Brown. 1975. Potential pathogens in the environment: cultural reactions and nucleic acid studies on Klebsiella pneumoniae from chemical and environmental sources. Appl. Microbiol. 29:819-825.

18. Seidler, R. J., and M. Mandel. 1971. Quantitative aspects of deoxyribonucleic acid renaturation: base composition, state of chromosome replication, and polynucleotide homologies. J. Bacteriol. 106:608-614.

19. Szybalski, W. 1968. Use of cesium sulfate for equilibrium density gradient centrifugation. Methods Enzymol. 12B:330-360.

20. Wetmur, J. G., and N. Davidson. 1968. Kinetics of renaturation of DNA. J. Mol. Biol. 31:349-370.

21. Wickerham, L. J. 1951. Taxonomy of yeasts, p. 1-56. Technical bulletin 1029. U. S. Department of Agriculture, Washington, D. C.

22. Wickerham, L. J., and K. A. Burton. 1956. Hybridiza. tion studies involving Saccharomyces lactis and Zygosaccharomyces ashbyi. J. Bacteriol. 71:290-295.

23. Winge, Ö., and 0 . Laustsen. 1939. On 14 new veast types produced by hybridization. C. R. Trav. Lab. Carlsberg, Ser. Physiol. 22:337-352. 